RÁCZ JÁNOS 2018. Kutyaszótár. 410 kutyafajta nevének eredete és a fajták bemutatása. Tinta, Budapest.

RANCZ IRÉN 2007. Kézdialmási tájszótár. ELTE Magyar Nyelvtörténeti, Szociolingvisztikai, Dialektológiai Tanszék, Budapest.

SinKOVITS FERENC 1997. Bácskai magyar időjóslás. Csantavér népi meteorológiája. Jugoszláviai Magyar Mủvelődési Társaság, Újvidék.

Stancsics Mihály 1846. Raff György'természethistóriája gyermekek számára. Emich Gusztáv, Pest.

SZENDREY ZSIGMOND - SZENDREY ÁKOS 1940. Részletek a készülő magyar babonaszótárból. Ethnographia 51/3: 321-336.

SZLATKY MÁRIA szerk. 1983. „Minden doktorságot csak ebböl kisértek.” Szemelvények a XVIXVII. század magyar nyelvü orvosi kézikönyveiböl. Magvető, Budapest.

TESz. = A magyar nyelv történeti-etimológiai szótára 1-3. Főszerk. BENKÖ LORÁND. Akadémiai Kiadó, Budapest, 1967-1976.

Ulicsni ViKTOR - SVANBERG, IngVAR- MolnÁR ZsOlt 2013. Folk knowledge of non-domestic mammals among ethnic Hungarians in North-Western Romania. North-Western Journal of Zoology 9/2: 383-398.

ÚMTsz. $=$ Új magyar tájszótár 1-5. Főszerk. B. LŐRINCZY ÉVA. Akadémiai Kiadó, Budapest, 19792010.

VAJKAI AURÉL 1948. Népünk természetismerete. Néptudományi Intézet - Kelet-Európai Tudományos Intézet, Budapest.

KICSI SÁNDOR ANDRÁS

\title{
Egy esztergomi passionale magyar nyelvü töredékei
}

1. Tanulmányomban egy 15. századról csonkán fennmaradt latin nyelvü kézirat két magyar nyelvű szövegtöredéke keletkezése körüli kérdéseket mutatom be. Az említett kötet az Esztergomi Főszékesegyházi Könyvtárban őrzött, MS I 178 jelzettel ellátott darab (KovÁcH 2006: 49). ${ }^{1}$ A táblákon több különböző időkből származó bejegyzés, tollpróba látható, valamint néhány terjedelmesebb latin töredék is, de ezekkel ebben a tanulmányban most nem foglalkozom. A magyar töredékek korszerü közlése mellett (a korábbi közlések téves olvasatot is tartalmaznak) a lehetséges lejegyzési időt, a fellelhető szövegpárhuzamokat és az azokkal való viszonyukat vizsgálom, a scriptor azonosításának kérdéseire csak érintőlegesen térek ki. Nehézséget jelent, hogy a megtalált párhuzamokkal nem teljesen egyezik a két töredék, emellett az egyedinek tünő betűformák és a két részlet némileg eltérő hangjelölése nehezíti a datálást.

A könyvecske hátsó tábláján két - vélhetően a 16. század közepén élt - possessor neve is látható, nagyon hasonló kézírással lejegyezve. Felül: ,gregorius chompor”, alatta: „gergiu؟ fzucz de comiati” - KovÁcH szerint Komjáti Szücs Gergely vagy György (2006: 49). A két birtokos közül az egyik bejegyzéshez csak egy esemény kapcsolódik: „gergiu؟ fzucz de comiati dedi fzapones viiij”. ${ }^{2}$ A két szövegrészletet az első és hátsó kötéstáblára valószínüleg a magát gregorius chompor-ként megnevező birtokos jegyezte le. A tulajdo-

${ }^{1}$ A kötet teljes egészében elérhető elektronikusan a könyvtár felületén: http://esztergom. bibliotheca.hu/scan/ms_i_178/index.html (2019.01.03.)

${ }^{2}$ Ezúton köszönöm lektorom hasznos észrevételeit. 
nosok személyeinek megfejtése segítené a datálást, de a chompor névalakkal összefüggő, történetileg adatolt névalakok szétválasztása az eredeti célkitüzéstől messzire vezetne, valamint a probléma összetettsége miatt a megoldás további kutatásokat igényel.

A szakirodalom hol az egyiküket (LÁNYI-KNAUZ 1866: 484; FRICK 1910: 67³; VARGHA 1913: $5^{4}$ ), hol a másikukat (RADÓ 1941a: 121-122, 1941b: 1725\% CSAPODI-CSAPODINÉ 1988: $327^{6}$ ) tartja a tulajdonosnak. Némi támpontot talán az jelenthetne, hogy a felső név halványabb tintával íródott, mint az alsó, és a töredék tintájának a fakóbb árnyalata ehhez közelebb áll. A második név írásképében a $d, g, s, z$ és $o$ grafémák némileg különböznek a másik név betüformáitól, de az egyértelmü különbségtételhez nagyobb terjedelmü szövegre lenne szükség. RADÓ megállapítása szerint a passionale törzsanyaga három kéz munkája: a 2. a 16. század végén, a 3. a 17. században írt a kötetbe. Lábjegyzetben a korábbi kutatásokat felülvizsgálandó észrevételt közöl: „Knauz itt »Chompor Gergely birtokában volt régi gradualéról« beszél. Mivel az általam kijegyzett szöveg az itt közölttel azonos, viszont nem gradualéba írta, hanem a passiók könyvébe, fel kell tételezni, hogy Knauz elcserélte valamilyen feljegyzéséből a nevet is (Chompor), könyvet is.” (RADÓ 1941a: 121-122).

2. Az elülső tábla belsején olvasható egy töredék, amely Pál apostol a rómaiakhoz írt levelének részlete (11,33-36), ahogy ezt a lejegyző latinul feltünteti. Hátul ötsornyi részlet olvasható a Te deumból. Az első töredék lehetséges forrásáról a szakirodalomban nem találtam semmit, a szövegből LÁNYI is csak egy részletet ad közre, amely valahol félúton lehet a betühü közlés, olvasat és értelmezés között (az interpretációs szintekre 1. JUHÁSz 2016): „O Istennek kazdagságának, és bölcseségének és értelmének mii wolta, mell igben megh tudhatatlanok az eu Ítéleti és wégére mehetetlenek az eu vtay, stb.” (LÁNYI-KNAUZ 1866: 484).

Szent Pál levelei közül a zsidókhoz írt található meg az 1516-1519 között készült Jordánszky-kódexben. Ellenben az 1508-as Döbrentei-kódex a perikóparendjében több részletet is tartalmaz a rómaiakhoz írt levélböl. Meg is található benne a kérdéses szakasz, de a töredéktől eltérő fordítási hagyományt felmutatva. Sőt feltételezhető, hogy a Jordánszky-kódexet bíró apácák is rendelkeztek egy 1480 körülröl való, már magyar nyelvü episztolafordítással, egy ilyen gyüjteményt egyébként Komjáti Benedek is említ előszavában (Ács 2011: 42-44). Pál leveleinek első, teljes terjedelmében ránk maradt magyar nyelvü fordítása ugyanis 1533-ban, Krakkóban kiadott Komjáti Benedek-féle nyomtatványban jelentkezik először, de részleteiben a Döbrentei-kódex szövegeivel rokonítható (ÁCs 2011: 39). Pesti Gábor 1536-os bibliafordításából hiányzik az egység.

${ }^{3}$ FRICK kiemeli a hasonlóságát a Peer-kódexszel, a töredéket 16. sz. elején készültnek véli.

${ }^{4}$ Itt hivatkozik az 1912-ben megjelent tanulmányára, ugyanis az ItK.-ben megjelent írására érkezett bírálat az Egyetemes Philologiai Közlöny 1912-es évfolyamának 382. lapján „A.” aláírással. A bíráló kifogásolja, hogy nem használta FRICK munkáját, abban ugyanis további kettő Te deum-töredék ismertetése is megtalálható. VARGHA azonban elhárítja a kritikát azzal, hogy ő kizárólag a teljes Te deum-fordításokkal foglalkozik. Egyébként itt a kötet sajtóhibával „Chompor-féle Gruduale-töredék" néven olvasható.

${ }^{5}$ Ö elöször 15. századinak tartja a nagyhét négy passióját tartalmazó, négysoros kottákat közlö papírkódexet, amelynek a 16. század első felében magyar tulajdonosa volt: „Gregorius Szucz de Comiati” (121-122). Szerinte Szücs munkája a passionale első és hátsó kötéstáblán megtalálható magyar nyelvű bejegyzések. Később a latin összefoglalásában a 16. századi gradualét „Gregorius Szücs de Komját" tulajdonának tekinti (172).

${ }^{6}$ Náluk tévesen Gergorius Szuch szerepel. 
Saját közlésemben a megerősítés miatt felragasztott szalagok által kitakart részeknek csak részben vagy egyáltalán nem olvasható, ezért utólag kikövetkeztetett betűi szerepelnek szögletes zárójelben. Indexbe tettem a lejegyzéssel egyidőben, interlineárisan beszúrt elemeket, $<\ldots>$ pedig a scriptor törlését jelöli. Mivel a korszakban a száras $\int$ jelenléte bizonyos pozíciókban jól követhetően felcserélődik $s$-sel és így korszakjelölő sajátossággal bír, ezért ezt a - jelentés szempontjából lényegtelen - betüformát megtartottam, bár a lejegyző mindkét töredékben kizárólag az $\int$ formát használja. A rubrummal írt részt félkövérrel szedtem. A teljesen pontos idézés azért fontos, mert a biztos olvasat elkészítését nehezítő következményei lehetnek a tagolásnak - erre majd a hátsó tábla töredéke kapcsán fogok kitérni.

\section{1. táblázat}

A Róm. 11, 33-36 a korai fordításokban

\begin{tabular}{|c|c|}
\hline $\begin{array}{l}\text { DöbrK: Zent haromsag } \\
\text { napian pal romaba XI } \\
(345)\end{array}$ & 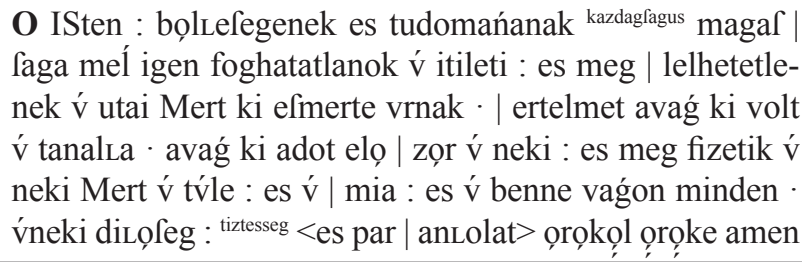 \\
\hline $\begin{array}{l}\text { Komjáti: Az romabelyeknek } \\
\text { yrth levelnek Tyzenegyedyk } \\
\text { Capitvlvm } \\
(1533: 89)\end{array}$ & 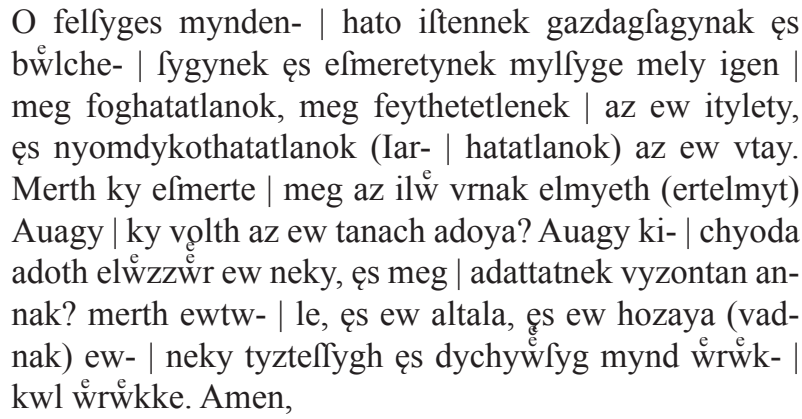 \\
\hline
\end{tabular}

Az első kötéstáblán látható töredék párhuzamát a Sylvester János 1541-ben nyomtatásban megjelent bibliafordításában találtam meg, így a passionale két töredékének lejegyzése legkorábban 1541-ben történhetett. A keletkezés pontosításának megkísérléséhez azonban további szempontokat is figyelembe vettem. Így most ezek alapján veszem sorra az ebben segítő jelenségeket, az általános helyesírási kérdéseket később, a második töredék közlése után fogom érinteni.

A levélfordítások kronológiai viszonya kapcsán említésre méltó lehet, hogy Sylvester a bibliafordításához felhasználhatott egy huszita bibliafordítási hagyományon alapuló másolatot, még ha talán nem is magát a Müncheni kódexet (vö. VARJAS 1960: 9). Csakhogy ezt a feltevést szövegpárhuzamokkal be kellene bizonyítani. Ha a lehetöséget követjük, hogy valaha létezett egy teljes huszita bibliafordítás, akkor Pál leveleinek töredékét végsősoron egy 1541 elötti szövegváltozatra is vissza lehetne vezetni. Ugyanakkor a töredék - a hátsó táblán található töredékhez hasonlóan - nem feleltethető meg teljesen vélhető forrásával, ez pedig árnyalja a keletkezési körülményeket. 
A köztes művek lehetőségét megengedve, betűforma alapján nem tudtam korábbi keletkezést támogató írnoki munkát találni. A ránk maradt, éppen 1541-ig feldolgozott kéziratokban is csak legfeljebb több szerzőtől egy-egy betüformára leltem párhuzamot az 1490-1526 körül készült iratokban: lásd Középkori leveleink 8., 12., 19., 26. és 27. illetve az 54. darab aláírását és 60 . darab magyar részét. A két magyar nyelvü töredéknek betüformái egyedinek tünnek. Ugyanakkor még ekkor is figyelembe kell venni a lejegyző egyéni szokásait a hangjelölésben, amelyek mindkét töredékben megmutatkoznak a forrásoktól való azonos eltérésben.

\section{2. táblázat}

A Róm. 11, 33-36 a Sylvester-féle hagyományban

\begin{tabular}{|c|c|}
\hline $\begin{array}{l}\text { Sylvester: Az fzent Pāl } \\
\text { apostolnak leuele melíet } \\
\text { az Romabelieknek irt, } \\
\text { Tizen̄egǵedik rifz: } \\
(1541: 17 \mathrm{r})\end{array}$ & 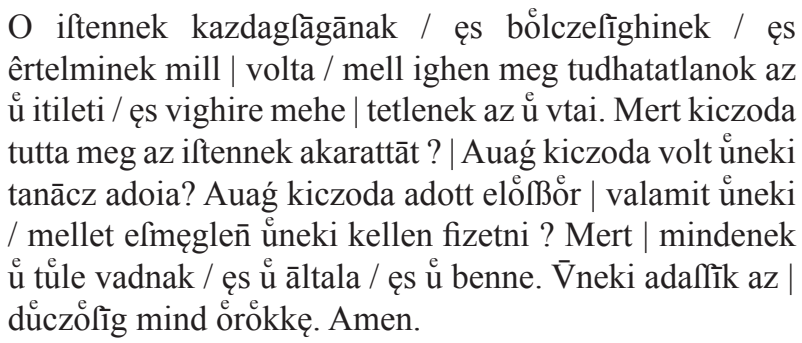 \\
\hline $\begin{array}{l}\text { Passionale töredéke: ad } \\
\text { romanos dacemō prim }[. . .]\end{array}$ & $\begin{array}{l}\text { O iftennek kazdagfaganak ef bolczefegenek ef ertel : } \\
\text { menek me }{ }^{\mathrm{e}} \text { volta mell ighen meg tudhatatlanok az } \\
\text { eu iteleti ef vegere mehetetlenek az eu vtaÿ mert } \\
\text { kiczoda tutta meg az iftennek akarattat ! auag kiczo } \\
\text { da volt euneki tanacz adoia auag kiczoda adot eloffor } \\
\text { valamit eu neki mellet ef meglen eu neki meg kel[1] } \\
\text { fizetni mert mindenek eu }{ }^{7} \text { tüle vadnak ef eu altal[a] } \\
\text { ef eu benne vneki adaffek az diczofeg mind oo rokke a[men] }\end{array}$ \\
\hline
\end{tabular}

Mindenképpen elgondolkodtató, hogy a töredékek nem szoros másolatok. Pál levelének részletében a tüle és o̊rokke adatokban az $u$ és $\ddot{o}$ hang jelölésében a nyomtatványnak megfelelő betük megjelennek. Csakhogy e két graféma már a magyar nyelvü nyomtatványok elött is jelentkezik a magyar kéziratos hangjelölési hagyományban, nem sokkal lemaradva a német hangjelölési rendszerben (SCHNEIDER 1999: 92) való kialakulásukat követően, sőt attól valószínűleg nem is függetlenül. Az 1380 körül keletkezett Königsbergi szójegyzékből (Gl. 41) adatolhatók: az $\stackrel{e}{o}$ jelölés az $\ddot{o}$ és az $\stackrel{e}{v}$ graféma az $\ddot{u}$ hang jeleként bukkan fel (KNIEZSA 1952: 95). Esetleg a töredék némileg későbbi létrejötte lehet ennek az oka: a töredék forrása egyéb korai mü is lehet, ebben az esetben a 16. század második harmadától kezdődő időszakasz jöhet szóba.

${ }^{7}$ A kötéstábla mindkét oldalán apró, fekete és barna foltok láthatók, e helyen úgy tünik, mintha eü lenne lejegyezve. A foltok miatt nem egyértelmü, hogy e jelölés szándékos, mindenesetre a töredékekben máshol nem fordul elö. 
A nyelvjárási sajátosságokat nem tartja meg a lejegyző, ezeket talán saját nyelvjárása szerinti változatában megfeleltethetőkkel helyettesíti. Az eltérések tekintetében hangjelölése tudatosságot mutat: Sylvester különböző mellékjeleit - legyen az magánhangzó hoszszúságát vagy annak más ejtésbeli sajátosságát, sőt mássalhangzók palatalizáltságát jelölő a fenti kivételeket nem számítva elhagyja. Az vtä̈ esetében Sylvesternél vtai alak van, az $\ddot{y}$ nem feltétlenül számít mellékjeles betünek a kor felfogásában.

A magánhangzó hosszúságát egyetlen egyszer jelöli a bibliatöredékben: a me $l$ 'mély' szóban utólagos betoldással létrehozott betükettőzésben. Ez a kódexek korában teljes egészében és következetesen soha nem használt rendszerrel egyeztethető. A későbbi kéziratoktól e tekintetben a nyomdatermékek elváltak: a nyomtatványok viszont inkább mellékjellel jelölték a hosszú magánhangzókat (TöRÖK 1956: 507).

Egyéb írás- és intonációs jelekben a forrástól eltérően szükölködik mindkét töredék: sem vesszőt, sem pontot, valamint egyéb tagolójelet sem tartalmaznak. Az első tábla szövegének esetében a forrásként feltehető Sylvester-féle fordításban fejlett központozást és szövegtagolást figyelhetünk meg, több ? jel is megtalálható - mondatzáró helyzeten kívül függő kérdés után is. A töredék egyetlen egyszer tartalmaz kérdőjelet, annak is a mai felkiáltójelhez hasonló alakját mutatja. Azaz ellentmondásos a viszony: vélhetően ismert a lejegyző intonációs jeleket, hiszen alakjában eltér, de funkciójában egyezik. A pont fölé írt félkör íve és szöge a korban szokás szerint ingadozó volt, sőt felkiáltó, felszólító mondat végén a kérdőjel is megjelenhetett. Külön funkcióban, külön jelként viszont a felkiáltójel a 16. század végén, kéziratokban csak a 17. század elején jelentkezett (KESZLER 2004: 121). Mindkét töredékben található egy-egy kettőspont: elválasztójelként a bibliai részletben és mondatzáró jelként a hátsó táblán.

Árulkodhat a keletkezés körülményéről a lejegyző nyelvtudása, ami a forrás megjelölésében mutatható ki. Sylvestertől magyarul is átvehető lett volna, mégis latinul jegyezte be a másoló a szakasz címét. Ezzel ellentétben a hátsó táblán álló ,gergius szucz de comati dedi fzapones viiij” bejegyzésben a névalakjában a latinos közlés redundáns (amennyiben a Komját és nem a Komjáti helynévre utal): a de comiat vagy a magyaros comiati forma ugyanazt fejezné ki. Sőt a keresztnév pedig georgius lenne helyesen, ide is behatol a feltehetően magyaros Gyërgy-féle ejtés. Továbbá a fzapones alakon (vö. latin sapo) is a magyaros $s z$-es írásmód látszik, ugyanis a régi magyar szapu száraz ürmértéknek feleltethető meg (BoGDÁn 1998: 345).

3. A hátsó tábla töredékének korábban két közlése jelent meg (LÁNYI-KNAUZ 1866: 484 és RADÓ 1941: 122), ezek egyike sem pontos. A számos hibán kívül egy szó téves olvasata mindkettőben megtalálható, ez a töredék közlésében a félkövérrel szedett kirar szó, amelyet korábban „kit az”-ként olvastak. A korábbi olvasatokban zavaró tényezőként hatott, hogy a dicső király szerkezetben a kirar névszói állítmányt tévesen kit névmással kezdődő tárgyas alárendelő mellékmondati bevezetőként értelmezték. Az eredetileg a király-hoz tartozó dicső így közbeékelt jelzője lett az Úristen-nek, a „kit az”-nak olvasott kirar-t pedig emiatt a következő sorhoz tartozónak érezték. A 16. század elején készült Peer-kódexben megtalálható teljes változattal összevetve semmiképpen sem fogadható el a „kit az”-féle olvasat. Ezt egyébként az íráskép sem támogatja, hiszen a $z$ betű mindig 3 alakban mutatkozik. 


\section{3. táblázat}

A töredék korábbi közlései

\begin{tabular}{|l|l|}
\hline $\begin{array}{l}\text { LÁNYI-KNAUZ 1866: } \\
484\end{array}$ & $\begin{array}{l}\text { téged isten mi dicérionch } \\
\text { téged wrnak mies wallonk } \\
\text { téged eorek isten mindenföldi állath } \\
\text { dicér, neked kerubin és serafin minden- } \\
\text { koron énekelnek szent szent Wr Isten, diczö, } \\
\text { kit az télies menország és föld fölséggel diczőséggel --- }\end{array}$ \\
\hline RADÓ 1941: 122 & $\begin{array}{l}\text { Teged isten mi diczer- | ionch, teged Wrnak mi es vallunk. } \\
\text { Teged eurek isten minden | foldi allat dicer. Neked Kerubin es } \\
\text { Serafin mindenkoron enekel- | nek. Szent szent Wristen diczo } \\
\text { kit az teles menorszag es fold | folseggel diczoseggel. }\end{array}$ \\
\hline
\end{tabular}

Az összes többi ómagyar kori kódexben szereplö Te deum-változattól eltérö, és egyedülálló módon még kottával is ellátott teljes szöveggel megfeleltethető részben ugyanis a király szó szerepel. Ennek értelmében a kérdéses hely a töredékben kirar-nak felel meg. Ilyen változatot sem a TESz. történeti adatai között, sem a nyelvjárási adatok között (kerál kërály kirá királl kürál) nem találunk, noha a (hangátvetéses) kilár alak (ÚMTsz. 3: 354) elég közeli hozzá. A kirar alak létrejöttében számolhatunk hasonulással, illetve egyszerüen téves lejegyzéssel is.

A Peer-kódexből származó részlet esetében nem az eredetihez képest tördeltem a szöveget, hogy a Te deum sorai egyértelmüen azonosíthatók legyenek. Bár KoVÁCH szerint az első nyolc sor fordítása olvasható a passionaléban (KOVÁCH 2006: 49), valójában a töredék a Peer-kódex megfelelöje alapján csak hat sor lenne. De mivel a harmadik sor hiányzik a hátsó kötéstáblára írt szövegből, így csak öt sorból áll a töredék.

\section{4. táblázat}

A töredék és párhuzama

\begin{tabular}{|c|c|}
\hline $\begin{array}{l}\text { A Peer-kódex megfe- } \\
\text { lelője (PeerK. 292- } \\
\text { 294) }\end{array}$ & $\begin{array}{l}\text { Iften teged dÿcheronkh teged wrnak mÿ es vallonk } \\
\text { Teged orouk iften menden fọldi allat dÿcher } \\
\text { Teneked mennneÿ angelok es mennneÿ feÿedelmek } \\
\text { Teneked cherwbin es feraphin mendenkoron enekelnek } \\
\text { Zenth iften Zent wr Zent vr iften dÿchọ keral' } \\
\text { Tel'l'es menorfag es fọld felfeges dÿchọfegeddel }\end{array}$ \\
\hline A töredék betűhủ átirata & 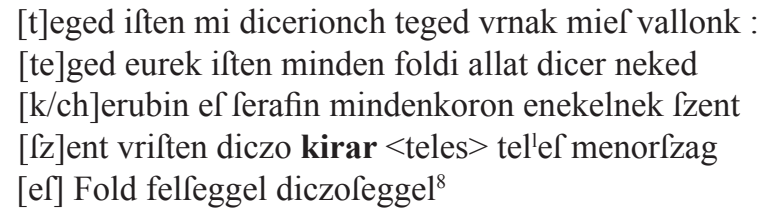 \\
\hline
\end{tabular}

\footnotetext{
${ }^{8} \mathrm{Az} \int$ betủ egy másik írásjel javításaként, arra ráírva szerepel.
} 
A Peer-kódex változata kronológiailag megelőzi a töredéket, a passionale első tábláján található töredék talán 1541 után készült, így a Te deum részlete legfeljebb azzal egy időben kerülhetett a hátsó táblára. Csakhogy e töredék esetében biztosabban tehető fel köztes szövegváltozat. Ugyanis a hátsó tábla töredéke sem közvetlen és nem is szoros másolata a Peerkódexbelinek, sokkal inkább emlékezetből lejegyzett szöveg, amely inkább a szóbeliségben élt. Az Szent Pál levelének részletén megfigyelhető hangjelölési sajátosságok mellett itt még a kihagyott sor is bizonyító erővel bír. Söt a kiemelt szerepü verskezdő szórend (ami alkalmas címelőzmény kialakulására, később az incipit jelentkezik a nyomtatványok tartalomjegyzékében is) felcserélése is ezt a feltevést erősíti. Ez kiemelten fontos, mert a Peer-kódexben található Te deum enélkül magányos változat lenne, így viszont feltételezhető, hogy szóbeli hagyományokra épülő változatot másoltak a kódexbe, annak scriptora nem feltétlenül azonos a fordítóval. E sajátos szöveghagyományhoz pedig a passionale részlete is csatlakozik.

4. A közlésekből jól látszik, hogy a két töredék hangjelölése között vannak egyező és eltérő tendenciák is. Közös jellemzőjük, hogy a mellékjeleket és írásjeleket eltüntette a lejegyző. A rövid és hosszú magánhangzó között csak egy kivétellel tesz különbséget betükettőzéssel. A palatális és nem palatális mássalhangzók eltérését nem jelöli mellékjellel, de még mellékbetủvel sem. Többjegyü, azaz betükapcsolatos jelölésmóddal várható hangok esetén feltünő az egyjegyüség is: a cs hang esetében: $c: c z$; az $s z$ hang esetében $\int: \int z$; valamint az $\ddot{O}$ és $O$ h hang esetében $o: e u$. A kéz sajátossága, hogy az $s$ graféma minden esetben a hosszú, száras $\int$ (bár erre kétféle betüformát használ), más variánsát (pl. szóvégen) nem alkalmazza. Ekkoriban már szóvégen tipikus az $s$ és betükapcsolatokban is kezd terjedni.

Néhány hang jelölésekor változatokat figyelhetünk meg, azaz több rendszert ismerhetett a lejegyző, vagy kevésbé valószínüen mindez a feltehető előzményszövegek hatása. A mellékjeles betük kapcsán-amennyiben előzmény jelenlétével, azaz másolással számolunkaz eddigi ellentmondások számát gyarapítaná az a feltevés, hogy a lejegyző nem ismerte a mellékjelek funkcióját és elhagyta azokat (vö. $n^{\prime}, g^{\prime}, l^{\prime}, t^{\prime}$ és $o$ ), hiszen így igen gyakorlatlan scriptor lenne. Sajátos jelölésmódja a bibliai részletben az $i$ hangértékben szereplö $\ddot{y}$. Ezenkívül csak abban a szövegben fordul elő két esetben a magánhangzó fölé tett $e$. Érdekes, hogy a levélrészletben egymás mellett szerepel az euneki és az vneki alak - köztes forrást feltéve elképzelhető, hogy az utóbbinál is mellékjeles grafémát lehet előzményként feltenni.

A Te deum töredékében viszont jelentkezik $c s$ hangértékben a $c z$ betükapcsolat mellett a $c$ graféma, és a latin serafin szótól eltekintve itt található 3 esetben $\int z$ betủpár, igaz, a bibliai részletben csak egy szóban jelentkezik az sz hang, de ott az ssz-hangot az $\iint$ betüpár jelöli. A $k$ hangértékü $c h$ is a második részlet sajátja, ezt a dicerionch szó lejegyzésénél látjuk. A cs hangot $c$ betü vagy $c z$ betüpár jelöli. A számos kódex és még a 17. századi protestáns nyomtatványok anyagaiban is a szóvégeken álló $c$ graféma $k$ hangértékben tipikus, szó elején szokatlan. Ennek $h$-val megtoldott változata a ch jelölés, az első táblában egy helyen látható ilyen szerepü graféma: ighen.

A töredékek keletkezéséhez közeli időben készült egyik kódexünk helyesírásában a ch gyakran jelentkezik $k$ hangértékben. Az 1529 és 1531 között készült Thewrewk-kódex 1. kezénél szövegenként eltérő mértékben, igaz, inkább szóvégi helyzetben, nem szó elején, mint a passionale töredékének említett adatában. Emellett szóbelseji helyzetben gyakori a $c$, szó elején azonban igen ritka, de van rá adat: capwÿa (ThewrK. 77). Az 5. 
kéznél pedig Krisztus nevének írásakor még $c z$ betü is jelöli a $k$ hangértéket, noha ez a betükapcsolat javarészt $c s$ hangot jelöl (ThewrK. 156, 159).

Jelen esetben viszont a szövegtöredékeken kívül a két atipikus megoldás talán együttesen is jelentkezik: Komjáti neve $c$-vel, azaz comiati alakban, míg a másik birtokos neve ch-s kezdettel, chompor alakban szerepel. Nem feltétlenül téves a vélhető lejegyző nevében a chompor névelemet $k$-val olvasni, hiszen a hátsó táblán is elöfordul egyszer a ch ilyen hangértékben. Ez több lehetőséget adva bonyolítja e névalak megfejtését, így a possessor egyértelmú azonosítását. Pedig a tulajdonosok meghatározása támpontot adhatna a töredék keletkezési idejének megállapítására.

Szóbeliségben létező szövegelőzményeket feltéve ezek az ingadozások a lejegyzőnek (a fejnek) sajátosságai. Köztes szövegek lehetőségét megengedve a két eltérő terjedelmü szövegtöredék eredetije két különböző időre és forrásra vezethető vissza. Ezért nem szabad figyelmen kívül hagyni, hogy ezek hangjelölési rendszerei befolyásolhatták a másolót, így az arányok némiképp torzítják az adatokat. A zárójelbe tett számok az előfordulások számát jelölik.

\section{5. táblázat}

A két töredék egyesített hangjelölési táblázata

\begin{tabular}{|c|c|c|}
\hline Hangok & Gyakori jelölés & Ritka jelölés \\
\hline $\mathrm{a}, \mathrm{a}$ & $\mathrm{a}$ & \\
\hline cs & $\mathrm{cz}(10 / 8)$ & $\mathrm{c}(10 / 2)$ \\
\hline e & e & \\
\hline é & $\mathrm{e}$ & $\mathrm{e}^{\mathrm{e}}(1)$ \\
\hline $\mathrm{g}$ & $\mathrm{g}$ & gh (1) \\
\hline gy & $\mathrm{g}(2 / 2)$ & \\
\hline $\mathrm{i}$ & $\mathrm{i}(30 / 29)$ & $\ddot{y}(30 / 1)$ \\
\hline $\mathrm{j}$ & $\mathrm{i}(1 / 1)$ & \\
\hline $\mathrm{k}$ & $\mathrm{k}(27 / 26)$ & $\operatorname{ch}(27 / 1)$ \\
\hline 1 & 1 & \\
\hline ly & $1(3 / 3)$ & \\
\hline $\mathrm{n}$ & $\mathrm{n}$ & \\
\hline ny & $\mathrm{n}(1 / 1)$ & \\
\hline o, ó & o & \\
\hline$\ddot{\mathrm{o}}, \mathrm{ö}$ & o $(19 / 10)$ & $\begin{array}{l}\text { eu }(19 / 7), \stackrel{\circ}{o}(19 / 1), \text { ? io } \\
(19 / 1)\end{array}$ \\
\hline $\mathrm{r}$ & $\mathrm{r}$ & \\
\hline $\mathrm{s}$ & $\Gamma$ & \\
\hline $\mathrm{sz}$ & fz $(5 / 3)$ & $\int(5 / 2)$ \\
\hline
\end{tabular}




\begin{tabular}{|l|l|l|}
\hline $\mathrm{t}$ & $\mathrm{t}$ & \\
\hline ty & $\mathrm{t}(1 / 1)$ & \\
\hline $\mathrm{u}, \mathrm{u}$ & $\mathrm{v}(5 / 3)$ & $\mathrm{u}(5 / 2)$ \\
\hline$\ddot{u}$, ủ & $\mathrm{v}(2 / 1), \mathrm{e}(2 / 1)$ & \\
\hline $\mathrm{v}$ & $\mathrm{v}(8 / 6)$ & $\mathrm{u}(8 / 2)$ \\
\hline $\mathrm{z}$ & $\mathrm{z}$ & \\
\hline
\end{tabular}

5. Összegzésként megállapítható, hogy az egyenként csupán néhány soros két töredék és a két bejegyzett név számos problémát felvet. Modern közlésükről nincs tudomásom, ezzel szemben a korábbiak pontatlanok voltak, ezért célszerủ volt a szövegeket megfelelően közre adni. Habár a szövegrészletek párhuzamai fellelhetők, kronológiai kérdésekben csak hozzávetőlegesen segítenek, mert egyik sem szoros másolat, illetve a mára csak a hiányukkal árulkodó korábbi irodalmi hagyományok feltételezése szintén akadályozza a keletkezés idejének biztos megállapítását. A két töredék hangjelölése különbözik a párhuzamos helyekétől, feltehető azonban, hogy mellékjeles helyesírástól eltérő hangjelölést preferáló személy munkái. Erre utalnak a minden megkülönböztető mellékjel vagy betüpár nélkül szereplő betük. A mintáktól való eltérésben következetességet mutató kéznek egyedi betüformái is vannak, amely szintén nehezíti a datálást.

A felismerhetö azonosság miatt mégis vélhetően 1541 után kerülhetett a passionale első táblájára Szent Pál rómbaleiekhez írt 11. levelének töredéke, illetve ezzel egy idöben a hátsó táblára ugyanattól a kéztől a valószínủleg emlékezetből felidézett Te deum-részlet. Ez utóbbi igen becses emlék, hiszen ez a Peer-kódex Te deumának fordításával rokon, így az nem tekinthető elszigetelt változatnak. A passionale töredéke nem közvetlenül a Peerkódexből való, így továbbra is kérdés marad a két szöveg közös előzményének keletkezési ideje. A kódex kottás változata is feltehetően már másolat, nem önálló fordítás.

Kulcsszók: Te deum laudamus, Szent Pál levelei, töredék, szövegközlés, hangjelölési rendszer, olvasat, keletkezési körülmények.

\section{Hivatkozott irodalom}

Abaffy Csilla - T. Szabó Csilla kiad. 1995. Döbrentei-kódex 1508. Régi Magyar Kódexek 19. Argumentum Kiadó, Magyar Nyelvtudományi Társaság, Budapest.

ÁCS PÁL 2011. Miért hiányoznak Szent Pál levelei a Jordánszky-kódex bibliafordításából? In: CSISZÁR GÁBOR - DARVAS ANIKÓ szerk., Klárisok. Tanulmánykötet Korompay Klára tiszteletére. ELTE Magyar Nyelvtörténeti, Szociolingvisztikai, Dialektológiai Tanszék, Budapest. 37-46.

BALÁZs JUDIT - UhL GABRIELLA kiad. 1995. Thewrewk-kódex 1531. Régi magyar kódexek 18. MTA Nyelvtudományi Intézet, Budapest.

BOGDÁN IsTVÁN 1998. Metrológia. In: BERTÉNYI IVÁN szerk., A történelem segédtudományai. Pannonica - Osiris Kiadó, Budapest. 331-350. 
CSAPODI CSABA - CSAPODINÉ GÁRDONYI KLÁRA 1988. Bibliotheca Hungarica. Kódexek és nyomtatott könyvek Magyarországon 1526 elött. I. Fönnmaradt kötetek: 1. A-J. A MTAK közleményei 23. Budapest.

FRICK JÓZSEF 1910. A középkori magyar himnuszköltészet. Stief Jenő és társa papirosáruházának könyvsajtója, Kolozsvár.

Gl. = Régi magyar glosszárium. Szerk. BERRÁR JOLÁN - KÁROLY SÁNDOR. Akadémiai Kiadó, Budapest, 1984.

JUHÁSZ DEZSŐ 2016. Interpretációs szintek a nyelvemlékek olvasásában és értelmezésében. In: BENÖ ATTILA - T. SzABÓ CsILlA szerk., Az ember és a nyelv-térben és időben. Erdélyi Múzeum-Egyesület, Kolozsvár. 183-190.

KESZLER BORBÁLA 2004. Írásjeltan. Az irásjelhasználat szabályai, problémái és története. Nemzeti Tankönyvkiadó, Budapest.

KNIEZSA ISTVÁN 1952. Helyesírásunk története a könyvnyomtatás koráig. Akadémiai Kiadó, Budapest.

Komjáti $=$ Comyathy Benedek 1533. Epistolae Pavli lingva hvngarica donatae. Az Zenth Paal leueley magyar nyeluen. Krakkó.

KovÁCH ZolTÁN 2006. Az Esztergomi Föszékesegyházi Könyvtár története a 11. századtól 1820-ig. Aula Kiadó Kft., Budapest-Esztergom.

Középkori leveleink = Középkori leveleink 1541-ig. Szerk. HEGEDÜS ATTILA - PAPP LAJOS. Tankönyvkiadó, Budapest, 1991.

LÁNYI KÁROLY - KNAUZ NÁNDOR 1866. Magyarország egyháztörténelme. I. kötet. Horák Egyed, Esztergom.

KACSKOVICS-REMÉNYi ANDREA - OsZKÓ BEATRIX kiad. 2000. Peer-kódex. Régi Magyar Kódexek 25. Magyar Nyelvtudományi Társaság - Argumentum Kiadó, Budapest.

RADÓ POLIKÁRP 1941a. Esztergomi könyvtárak liturgikus kéziratai. A Pannonhalmi Föapátsági Szent Gellért Főiskola évkönyve az 1940/1941-I tanévre. 84-142.

RADÓ POLIKÁRP 1941b. Index Codicum Manu Scriptorum liturgicorum Regni Hungariae. A Pannonhalmi Föapátsági Szent Gellért Föiskola évkönyve az 1940/1941-I tanévre. 143-202.

SCHNEIDER, KARIN 1999. Paläographie und Handschriftenkunde für Germanisten. Max Niemeyer Verlag, Tübingen.

Sylvester $=$ Joannes Syluester 1541. Vy Testamentū Maǵar ńelwen̄ melĺet az Gờò̃g es Diak ńelwbỏl vyonnan fordÿtank az Maǵar nipnek Keresztén hütben valo ippülisire. Sárvár-Újsziget.

TESz. = A magyar nyelv történeti-etimológiai szótára 1-3. Főszerk. BENKŐ LORÁND. Akadémiai Kiadó, Budapest. 1967-1976.

TÖRÖK GÁBOR 1956. Írott nyelvünk egységesülésének egy mozzanata. In: BÁRCZI GÉZA BENKÖ LORÁND szerk., Pais-emlékkönyv. Nyelvészeti tanulmányok. Akadémiai Kiadó, Budapest. 507-511.

ÚMTsz. = Új magyar tájszótár 1-5. Főszerk. B. LŐRINCZY ÉVA. Akadémiai Kiadó, Budapest. 1979-2010.

VARGHA DAMJÁN 1913. Te Deum és Te Mariam fordítása kódexirodalmunkban. Stephaneum Nyomda, Budapest. [Különnyomat a Békefi-emlékkönyvböl.]

VARJAS BÉLA 1960. Sylvester János Új Testamentum Újsziget 1541. [Kísérő tanulmány.] Magyar Tudományos Akadémia Irodalomtudományi Intézete, Budapest. 


\section{Hungarian fragments in a passional from Esztergom}

In a fragmentary Latin passional from the fifteenth century, kept in the Library of Esztergom Cathedral (MSS. I. 178.), two Hungarian text fragments can be found on the inside of the front and back covers, respectively. The first text fragment can be related to St Paul's letter to the Romans 11.33-36, from János Sylvester's 1541 translation of the Bible, while the second can be related to the Te deum of the Peer Codex, but neither of them is a direct copy of those texts. In the case of the first fragment, the effect of an earlier written text can be suspected, and in the case of the second, oral tradition may have played a role. Thus, the parallels give but limited chance for establishing the time of writing. On the back cover, in almost identical handwriting, the names of two possible owners can also be read: gregorius chompor, and gergiu fzucz de comiati. The unique letter shapes and the system of orthography represented in a limited data set also fail to give us sufficient clue for an unambiguous clarification of the circumstances of emergence of the fragments.

Keywords: Te deum laudamus, St Paul's letters, fragment, text publication, system of representation of sounds, reading, circumstances of emergence.

NÉMETH DÁNIEL

ELTE Eötvös Loránd Tudományegyetem

\section{SZÓ- ÉS SZÓLÁSMAGYARÁZATOK}

\section{Töröklö*}

1. A címként szereplő szó a SzT.-ból való: „töröklőrúd '?’ 1637: Az specificalt agyuk mind vasas kerekejuvel tengelyejuel agyaival es por kalannyual teöreökleö rudgyaiual eggywtt vadnak | Bathori bastya ... Mindenik agyunak vasas agy, kerekej, tengely, por kalanny; teöreökleö rudgyajual vadnak [Fog.; UF I, 396, 397].” Egy másik szócikkben olvasható: „törökölő '?’ 1679: vagy(on) ezen eresz alatt: ház tölteset tőröklő (!) nyelves Sulyok no 5. nyeles Sajtár nro 1 [Uzdisztpéter U; TL. Bajomi János inv. 12].” A felkiáltójel az idézetben bizonyára a következő szócikk szavával való esetleges kapcsolatra figyelmeztet.

2. A töröklö szó töve a tör ige lehet. Utóbbiból van képezve a törek, amint a TESz. írja is $(t o ̈ r+-k)$, a szótár az alapszónak 'valamit részeire választ; szétzúz' jelentést ad meg. Maga a törek a régiségben (is) 'gabonaszár és kalász törmeléke' jelentésü, és már a BesztSzj.-ből adatolható. 'Trágya' és 'rom' jelentésű adatai 1809-ből, valamint 1832-ből ismeretesek. SIMONYI ZSIGMOND (1877: 295) a törék > törek alakulást feltételezett. IMRE SÁNDOR (1863: 335) szerint a ripők, a pirók is efféle képzés (vö. TESz.). A - $k$ deverbális névképző az ún. öröklött képzőrendszer tagja, amely mintegy új erőre kapott a hozzá kapcsolódó igeképzőkkel (SZEGFÜ 1991: 189, 196-197); az -ëk > -ék képző alakulása szerep nélküli elem és képző kapcsolatából magyarázható: festék, keverék, Numarek 'Nyomorék'

*A szerző mindkét névtelen lektorának köszöni értékes megjegyzéseiket. 